\title{
Weighing Lysimeters for Developing Crop Coefficients and Efficient Irrigation Practices for Vegetable Crops
}

\author{
David R. Bryla ${ }^{1}$ \\ U.S. Department of Agriculture, Agricultural Research Service, Horticultural Crops Research Unit, \\ 3420 NW Orchard Avenue, Corvallis, OR 97330 \\ Thomas J. Trout \\ U.S. Department of Agriculture, Agricultural Research Service, Water Management Research Unit, \\ Fort Collins, CO 80526 \\ James E. Ayars \\ U.S. Department of Agriculture, Agricultural Research Service, Water Management \\ Research Unit, Parlier, CA 93648
}

Additional index words. crop water requirements, drainage, evapotranspiration, irrigation scheduling, microirrigation, water use efficiency

\begin{abstract}
Large, precision weighing lysimeters are expensive but invaluable tools for measuring crop evapotranspiration and developing crop coefficients. Crop coefficients are used by both growers and researchers to estimate crop water use and accurately schedule irrigations. Two lysimeters of this type were installed in 2002 in central California to determine daily rates of crop and potential (grass) evapotranspiration and develop crop coefficients for better irrigation management of vegetable crops. From 2002 to 2006, the crop lysimeter was planted with broccoli, iceberg lettuce, bell pepper, and garlic. Basal crop coefficients, $K_{\mathrm{cb}}$, defined as the ratio of crop to potential evapotranspiration when the soil surface is dry but transpiration in unlimited by soil water conditions, increased as a linear or quadratic function of the percentage of ground covered by vegetation. At midseason, when groundcover was greater than $70 \%$ to $90 \%, K_{\text {cb }}$ was $\approx 1.0$ in broccoli, 0.95 in lettuce, and 1.1 in pepper, and $K_{\mathrm{cb}}$ of each remained the same until harvest. Garlic $K_{\mathrm{cb}}$, in comparison, increased to 1.0 by the time the crop reached $80 \%$ ground cover, but with only $7 \%$ of additional coverage, $K_{\mathrm{cb}}$ continued to increase to 1.3 , until irrigation was stopped to dry the crop for harvest. Three weeks after irrigation was cutoff, garlic $K_{\mathrm{cb}}$ declined rapidly to a value of 0.16 by harvest. Yields of each crop equaled or exceeded commercial averages for California with much less water in some cases than typically applied. The new crop coefficients will facilitate irrigation scheduling in the crops and help to achieve full yield potential without overirrigation.
\end{abstract}

Nearly 1.25 million hectares of vegetables were irrigated in the United States in 2008 (USDA NASS, 2009). Most vegetable crops are shallow-rooted and sensitive to even mild soil water deficits and therefore normally require irrigation for commercial production. Growers thus try carefully to avoid underirrigation of vegetable crops, although overirrigation is costly and often reduces crop quality. To schedule irrigations properly, accurate estimates of the water requirements of the vegetable crops are needed.

A dependable method to estimate crop water requirements is a simple procedure whereby water lost by soil evaporation and

Received for publication 14 Jan. 2010. Accepted for publication 3 Aug. 2010.

This work was funded in part by Calif. State Univ. Agricultural Research Initiative, Calif. Dept. of Water Resources, and U.S. Bureau of Reclamation. We thank staff members from the USDA-ARS Water Management Research Unit in Parlier, CA, for providing technical assistance.

Mention of a trademark, proprietary product, or vendor does not constitute a guarantee or warranty of the product by the U.S. Dept. of Agriculture and does not imply its approval to the exclusion of other products or vendors that also may be suitable.

Part of a colloquium (The Efficient Use of Alternative Water and Traditional Irrigation Sources in Horticulture) presented 25 July 2009 at ASHS-2009, St. Louis, MO; sponsored by the Water Utilization and Management (WUM) Working Group.

${ }^{1}$ To whom reprint requests should be addressed; e-mail david.bryla@ars.usda.gov. plant transpiration, referred to collectively as crop evapotranspiration $\left(\mathrm{ET}_{\mathrm{c}}\right)$, is calculated by multiplying weather-based estimates of evapotranspiration from a reference crop such as grass $\left(\mathrm{ET}_{\mathrm{o}}\right)$ or alfalfa $\left(\mathrm{ET}_{\mathrm{r}}\right)$ by an empirically derived crop coefficient $\left(K_{\mathrm{c}}\right)$ used to account for specific conditions of the crop (Allen et al., 1998; Snyder et al., 1987a, 1987b; Wright, 1982). The $K_{\mathrm{c}}$ can be divided into two separate coefficients: a basal crop coefficient, $K_{\mathrm{cb}}$, for crop transpiration, and a soil water evaporation coefficient, $K_{\mathrm{e}}$, to account for the effects of soil wetting events caused by rain or surface irrigation. The use of a dual crop coefficient is more complicated than a single crop coefficient approach but is recommended when better estimates of $\mathrm{ET}_{\mathrm{c}}$ are needed such as when scheduling irrigation for frequent water applications using drip or automated sprinklers (Allen et al., 1998 ). Although $K_{\mathrm{c}}$ and $K_{\mathrm{cb}}$ values have been reported for a number of crops, the list is by no means complete. Accurate $K_{\mathrm{c}}$ values are difficult and expensive to develop, and because many fruits and vegetables are minor crops with a wide range of cultivar differences, most research in this area has focused on crops with large acreage such as wheat, corn, and cotton.

Currently, the most accurate way to estimate crop water use and develop crop coefficients is with precision weighing lysimeters, which has generally been regarded as the standard against which other measures of ET have been compared. Weighing lysimeters determine ET directly by mea- suring changes in mass of a soil container with plants positioned on a scale or other weighing device. They have been in use for measuring crop water use since the first one was constructed in Coshoctan, OH, in 1937 (Harold and Dreibelbis, 1951). Many others have been built since at locations throughout the United States and other countries with considerable improvements over the years (see Howell et al., 1991 for review), including more sensitive scale systems, computerized data acquisition and control functions (irrigation, drainage, etc.) (Howell et al., 1985), the use of intact soil monoliths (Schneider et al., 1998), and processing methods for better smoothing of noisy lysimeter data (Malone et al., 2000; Vaughn and Ayars, 2009; Vaughn et al., 2007). Examples of crops measured with lysimeters include various field crops such as alfalfa, corn, cotton, soybean, and wheat (e.g., Evett et al., 2000; López-Urrea et al., 2009a) as well as numerous horticultural species such as broccoli (López-Urrea et al., 2009b), cantaloupe (Ayars et al., 1999), garlic (Ayars, 2007), grape (Williams et al., 2003a, 2003b), muskmelon (Lovelli et al., 2005), onion (LópezUrrea et al., 2009c; Piccinni et al., 2009), peach (Johnson et al., 2000, 2002), spinach (Piccinni et al., 2009), sweet corn (Ayars et al., 1999), and tomato (Ayars et al., 1999; Phene et al., 1985).

Accuracy of lysimeter ET measurements varies depending on area and mass of the lysimeter as well as the type of scale system used, but many are precise within 0.02 to 0.05 $\mathrm{mm}$ of water use (Howell et al., 1991). This 
high a resolution requires the ability to detect very small weight changes in large soil volumes. For example, to measure $0.05 \mathrm{~mm}$ of water use, the lysimeter must detect a weight change of only $0.01 \mathrm{~kg} \cdot \mathrm{m}^{-2}$ of soil surface area. Large counterweights are typically used to offset the container and soil mass to permit precise measurements of soil evaporation and crop transpiration. Crop growth within the lysimeter tank should duplicate the field conditions where the data will be collected, and the crop surrounding the lysimeter should be similar to that inside the lysimeter (Allen et al., 1991; Pruitt and Lourence, 1985). The lysimeter should be situated within a field that is as level as possible and away from any obstructions that potentially alter radiation and wind patterns. Many investigators recommend an upwind fetch, with the same uniform crop as in the lysimeter, for a distance of greater than $50 \mathrm{~m}$ and a site area of at least $1 \mathrm{ha}$.

Two large weighing lysimeters, one for crops and one for grass, were constructed in 2002 at the University of California West Side Research and Extension Center (WSREC) located near Five Points, CA. The climate at the Center is Mediterranean-like with cool winters and an average annual precipitation of $215 \mathrm{~mm}$ (1983 to 2005). The project is long-term and is aimed at developing crop coefficients for vegetable crops produced in the semiarid San Joaquin Valley of central California. The San Joaquin Valley is one of the most productive agricultural regions in the world and is a leading producer of many vegetable crops. This article briefly reviews the use of the weighing lysimeters between 2002 and 2006 in development of crop coefficient curves for broccoli, iceberg (head) lettuce, bell pepper, and garlic.

\section{LYSIMETER CONSTRUCTION AND DESIGN}

Each lysimeter consists of a $2 \mathrm{~m} \times 2 \mathrm{~m} \times$ 2.25-m deep steel soil tank positioned on a mechanical tank scale (Model FS-4; Cardinal Scale Manufacturing Co., Webb City, MO) housed inside an underground steel enclosure with a concrete floor (Fig. 1). The lysimeters are similar in design to the type described by Lourence and Moore (1991). They were purchased from Precision Lysimeters (Red Bluff, CA) in 2001 at a cost of $\$ 47,000$ each, which included the steel enclosure and tank, the scale system, an access hatch and ladder, and delivery. Additional costs included soil excavation, installation of the concrete pads, crane rental to position the steel tanks and enclosures at the site, water and power supply to the lysimeters, data loggers, and labor.

The scale is a double wishbone type with a transverse lever assembly, which extends out into an underground access chamber to accommodate counterweights (Fig. 1D). The scale system ratio is equal to $100: 1$ at the point of counterweight and therefore $10 \mathrm{~kg}$ of lead weight counterbalances $\approx 1000 \mathrm{~kg}$ in the soil tank. A precision load cell is located on a pull rod connecting the shelf lever to the weigh beam, producing a nominal signal of
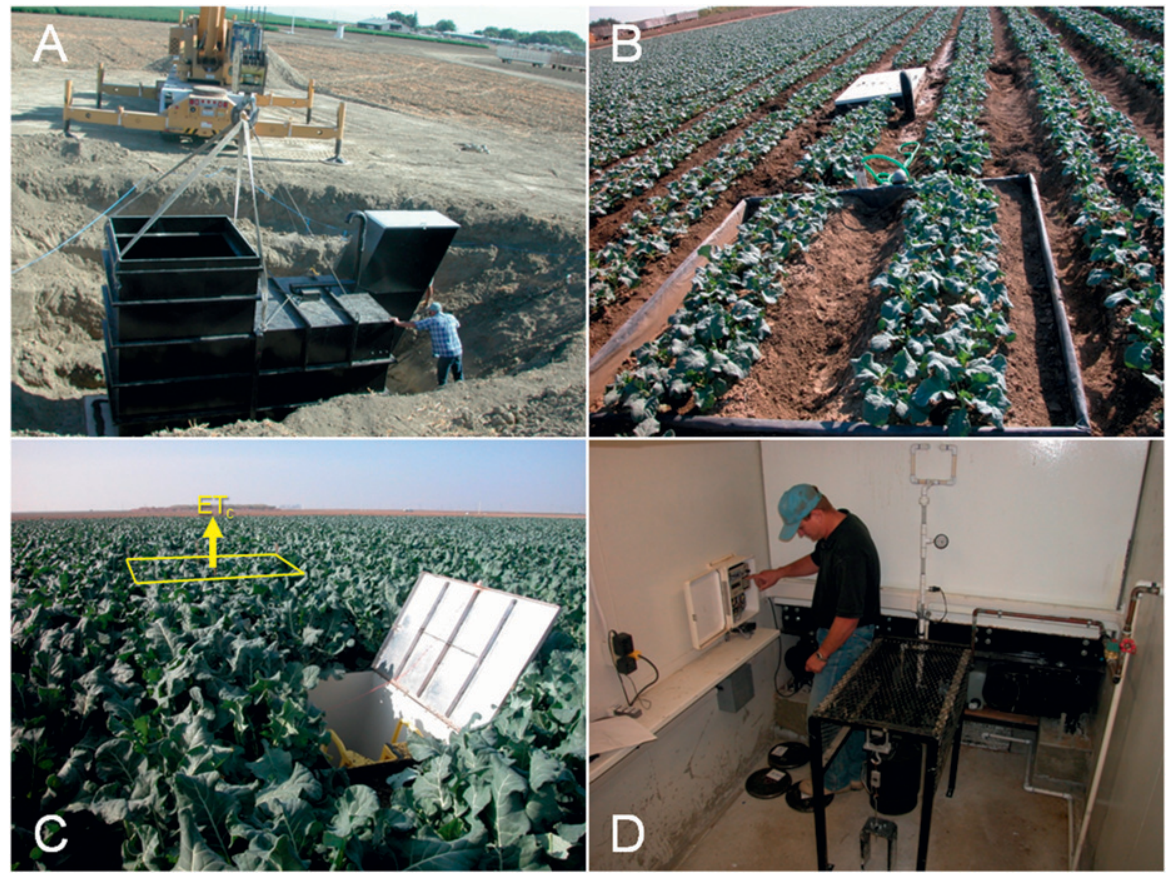

Fig. 1. (A) Installation of a steel enclosure for the crop lysimeter. The crop lysimeter was first planted with broccoli on 19 Aug. 2002 and is shown here at (B) $38 \mathrm{~d}$ and (C) $86 \mathrm{~d}$ after planting. (D) Inside the lysimeter enclosure. A 14-t soil tank is placed on a counterbalanced scale system and a data logger is used to monitor weight changes in the lysimeter tank resulting from crop evapotranspiration.

$4 \mu \mathrm{V} \cdot \mathrm{kg}^{-1}$ of weight change on the soil tank. More sensitive load cells are available, but the less sensitive model gives more margin of protection from overload. The weigh beam is scaled from 0 to $1500 \mathrm{~kg}$ in $0.1-\mathrm{kg}$ increments equivalent to $0.025 \mathrm{~mm}$ of water weight change on the soil tank. The load cell was calibrated by placing known weights in the range of 20 to $200 \mathrm{~kg}$ on the lysimeter surface.

Soil at the site is a Panoche clay loam (Typic Torriorthents) with relatively uniform water retention characteristics and high water-holding capacity averaging over $425 \mathrm{~mm}$ in the top $2.5 \mathrm{~m}$ (Nielsen et al., 1973). The soil was carefully removed in $0.3-\mathrm{m}$ increments during excavation for the lysimeters and repacked in the soil tanks and around the enclosures at approximately the same depth and soil density as the surrounding field. The gap between the soil tank and enclosure wall of the lysimeters is less than $2 \mathrm{~cm}$ on all sides with the top edges of each located $\approx 5 \mathrm{~cm}$ above level field grade. The gaps were covered with EPDM nylon fabric glued to the inside of the soil tank and outside to the outer enclosure wall with rubber cement. The fabric was looped upward $\approx 0.5 \mathrm{~cm}$ above the tank edge to avoid any tension on the soil tanks. Soil above each underground access chamber is $\approx 0.95 \mathrm{~m}$ deep. Sufficient soil depth on all sides of the soil tanks is critical to maintain similar soil temperatures between the field and soil tanks and to establish a healthy crop and adequate drainage in the vicinity of the field surrounding the tanks.

The basic data obtained from the lysimeters are weight loss resulting from crop or grass ET and weight gain resulting from precipitation and irrigation, in which $4 \mathrm{~kg}$ equals $1 \mathrm{~mm}$ of water over the $4-\mathrm{m}^{2}$ surface area. Weight changes measured by the load cell are recorded hourly using a Campbell Scientific CR3000 data logger, upgraded from a CR-21X in 2006 (Logan, UT). An irrigation water supply tank is hung on the underside of the soil tank and refilled nightly, between $2400 \mathrm{HR}$ and $0100 \mathrm{HR}$ to a reference weight to replace any water consumed the previous day. The soil tank is irrigated from the supply tank each time the lysimeter weight decreases by $4 \mathrm{~kg}$ (i.e., $1 \mathrm{~mm}$ of water use). That way, irrigations involve only a transfer of water from the supply tank to the soil tank, resulting in no irrigation weight changes during the day, and the lysimeter weight declines continuously as water is transpired by the plants and evaporated from the soil surface (Phene et al., 1989). Irrigation is applied by drip tubing installed $0.2 \mathrm{~m}$ deep in the crop lysimeter and $0.1 \mathrm{~m}$ deep in the grass lysimeter and measured by a flow meter (IR-Opflow Type 1; JLC Intl., New Britain, PA). Excess rainfall or irrigation that percolates to the bottom of the soil tank drains by gravity through a polyvinyl chloride drainage manifold and is measured using a Campbell Scientific model TE525MM rain gauge (Logan, UT) located on the floor under the tank.

The lysimeters are each located near the center of adjacent, laser-leveled 1.8-ha fields $(\approx 90 \mathrm{~m} \times 200 \mathrm{~m})$. The fields are surrounded by other fields planted with various low annual crops such as cotton and processing tomato. The crop lysimeter and field were planted with broccoli in Fall 2002, iceberg lettuce in Fall 2004, bell pepper in spring to Summer 2005, and garlic in Winter to Summer 2006. Fertilization, thinning, and weed and pest control 

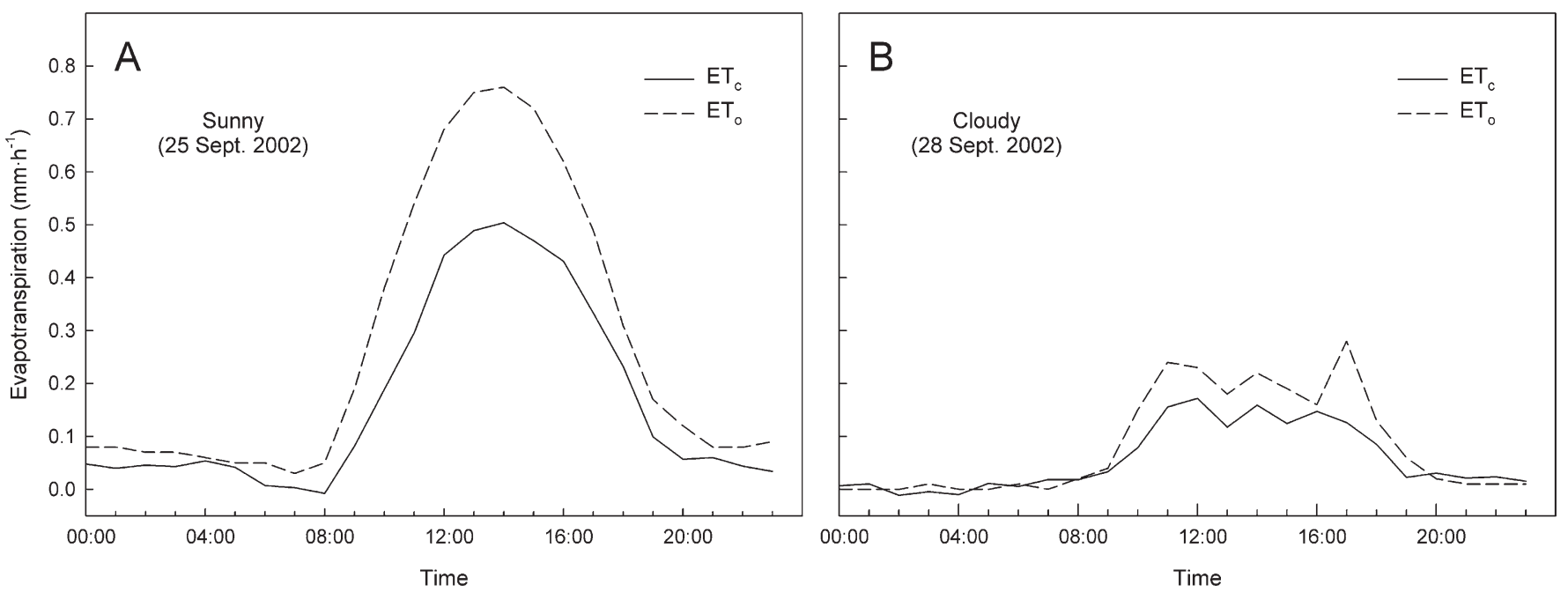

Fig. 2. Hourly rates of crop (broccoli) evapotranspiration $\left(\mathrm{ET}_{\mathrm{c}}\right)$ and reference evapotranspiration $\left(\mathrm{ET}_{\mathrm{o}}\right)$ on a sunny day $(\mathbf{A})$ and a cloudy day $(\mathbf{B})$ near Five Points, $\mathrm{CA}$.

were done following standard cultural practices for the region. The fraction of ground covered or shaded by vegetation $\left(f_{\mathrm{c}}\right)$ in the lysimeter was measured periodically each growing season using an ADC multispectral camera (TetraCam, Chatsworth, CA) mounted on a frame $1.5 \mathrm{~m}$ above the bed surface and imaging-editing software provided with the camera, following the procedures outlined by Trout et al. (2008). The lysimeter and field were also planted with bell pepper in 2003 and lettuce in Spring 2004, but crop growth in and around the lysimeter on these dates was nonuniform; therefore, the data were not used to develop crop coefficients. The grass field was planted with tall fescue (Festuca arundinacea Schreb.) in Fall 2002. The grass is irrigated by subsurface drip laterals spaced $0.3 \mathrm{~m}$ apart and $0.1 \mathrm{~m}$ deep in the vicinity of the lysimeter and by pop-up sprinklers on the outer edges of the field and is mowed weekly, or as needed in cooler months, to a height of $0.1 \mathrm{~m}$.

A California Irrigation Management Information System (CIMIS) weather station (\#2) is located $7 \mathrm{~m}$ from the grass lysimeter. The ASCE standardized reference evapotranspiration equation (ASCE-EWRI, 2005) was used to calculate $\mathrm{ET}_{\mathrm{o}}$ with weather data downloaded from the CIMIS web site (http://www.cimis.water.ca.gov). Crop coefficients were calculated as the ratio of daily $\mathrm{ET}_{\mathrm{c}}$ measured on the crop lysimeter to $\mathrm{ET}_{\mathrm{o}}$ calculated from the CIMIS weather station data. The $K_{\mathrm{c}}$ calculations were based on CIMIS $\mathrm{ET}_{\mathrm{o}}$ rather than lysimeter $\mathrm{ET}_{\mathrm{o}}$ because the intended function of the values is for estimating crop ET from weather data (Allen et al., 1998). The grass lysimeter was used primarily to evaluate CIMIS $\mathrm{ET}_{\mathrm{o}}$.

\section{DEVELOPING CROP COEFFICIENTS}

On normal cloudless days in central California, the crop lysimeter typically generated smooth daily ET graphs with minimal noise (Fig. 2A). On cloudy days, on the other hand, the lysimeter data were more variable,

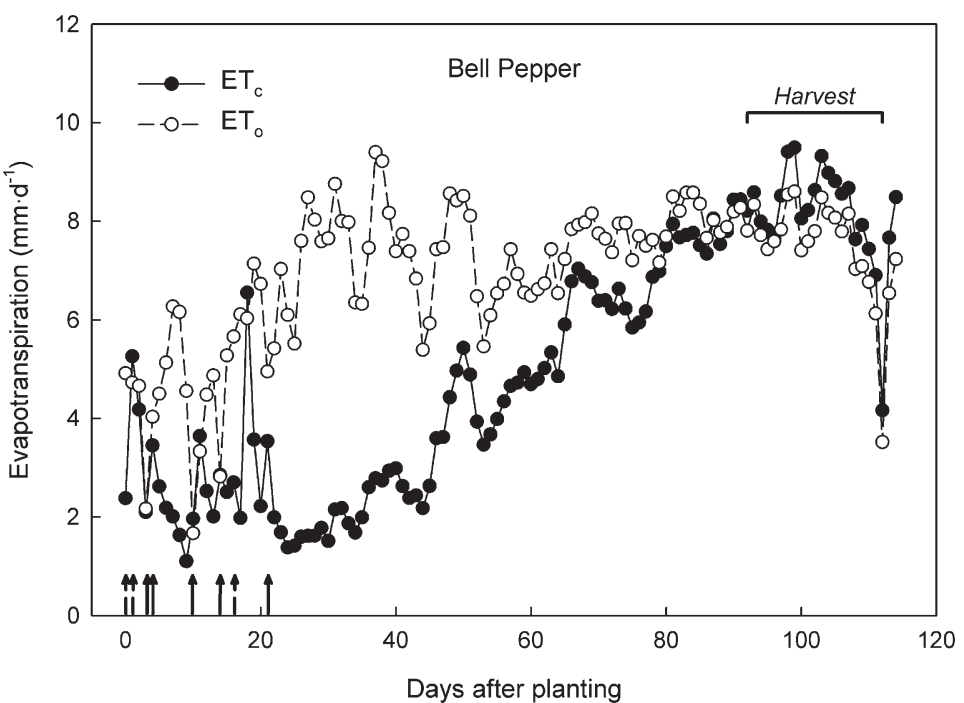

Fig. 3. Daily rates of crop (bell pepper) evapotranspiration $\left(\mathrm{ET}_{\mathrm{c}}\right)$ and reference evapotranspiration $\left(\mathrm{ET}_{\mathrm{o}}\right)$ from planting (25 Apr. 2005) to harvest (25 July to 16 Aug. 2005). Solids arrows on the $\mathrm{X}$-axis indicate rain events and broken arrows indicate days the crop was irrigated by sprinklers. Data are from Trout and Gartung (2006).

as light conditions changed over the course of the day, but $\mathrm{ET}_{\mathrm{c}}$ generally followed the same pattern as $\mathrm{ET}_{\mathrm{o}}$, resulting in consistent dayto-day $K_{\mathrm{c}}$ values (i.e., ratio of $\mathrm{ET}_{\mathrm{c}}$ to $\mathrm{ET}_{\mathrm{o}}$ ) (Fig. 2B). Hourly $\mathrm{ET}_{\mathrm{c}}$ and $\mathrm{ET}_{\mathrm{o}}$ values were summed each day to calculate daily $K_{\mathrm{c}}$. Using the data in Figure 2, daily $K_{\mathrm{c}}$ values on 25 and 28 Aug. 2002 were 0.63 and 0.69 , respectively.

A typical seasonal relationship between $\mathrm{ET}_{\mathrm{c}}$ and $\mathrm{ET}_{\mathrm{o}}$ is illustrated in Figure 3 for bell pepper. Daily $\mathrm{ET}_{c}$, in this case, ranged from less than $2 \mathrm{~mm} \cdot \mathrm{d}^{-1}$, early in the season, when plants were small and the soil surface was dry, to $\approx 8$ to $9 \mathrm{~mm} \cdot \mathrm{d}^{-1}$ during the peak ET period in late July to early August, when plants reached full effective cover and the peppers were ready for harvest. The effects of a wet soil surface from sprinklers and rain are evident during the first $20 \mathrm{~d}$ after planting by the fact that $\mathrm{ET}_{\mathrm{c}}$ after each event was nearly equal to or greater than $\mathrm{ET}_{\mathrm{o}}$. A method for estimating the crop coefficient for soil water evaporation, $K_{\mathrm{e}}$, most important immediately after rain or surface irrigation, is described elsewhere (Allen et al., 1998).

The crop coefficient curves computed from daily $\mathrm{ET}_{\mathrm{c}}$ and $\mathrm{ET}_{\mathrm{o}}$ data are shown in Figures 4 through 7 . In each case, the data were fit with a FAO segmented basal crop coefficient, $K_{\mathrm{cb}}$, curve at three or four stages of crop growth, including the initial stage $\left(K_{\mathrm{cb} \text { ini }}\right)$ that starts at planting and goes to when $\approx 10 \%$ of the soil surface is covered by green vegetation, the crop development stage $\left(K_{\mathrm{cb} \text { dev }}\right)$ that runs from $10 \%$ cover to full effective cover (defined in row crops as the stage when leaves between rows begin to intermingle or, if no intermingling occurs, when plants reach nearly full size), the midseason stage $\left(K_{\mathrm{cb} \text { mid }}\right)$ that covers the period 


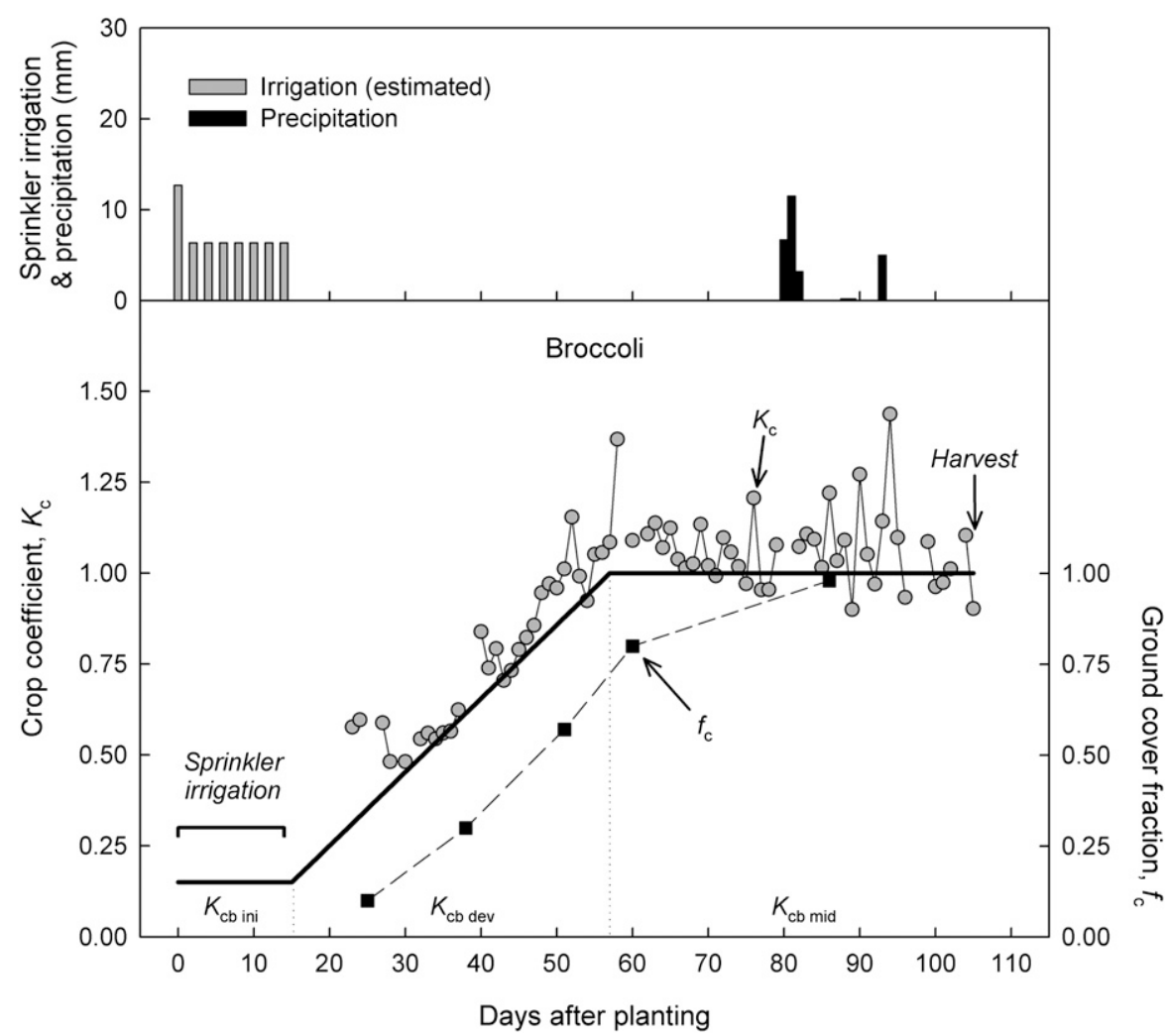

Fig. 4. Daily crop coefficients $\left(K_{\mathrm{c}}\right)$ and vegetative ground cover fraction $\left(f_{\mathrm{c}}\right)$ for broccoli from $23 \mathrm{~d}$ after planting (planted 19 Aug. 2002) to harvest (2 Dec. 2002). The heavy line represents the FAO segmented basal crop coefficient $\left(\mathrm{K}_{\mathrm{cb}}\right)$ curve at three stages of crop growth (initial period, $K_{\mathrm{cb}}$ ini; crop development period, $K_{\mathrm{cb} \text { dev }}$; and midseason period, $K_{\mathrm{cb} \text { mid }}$ ).

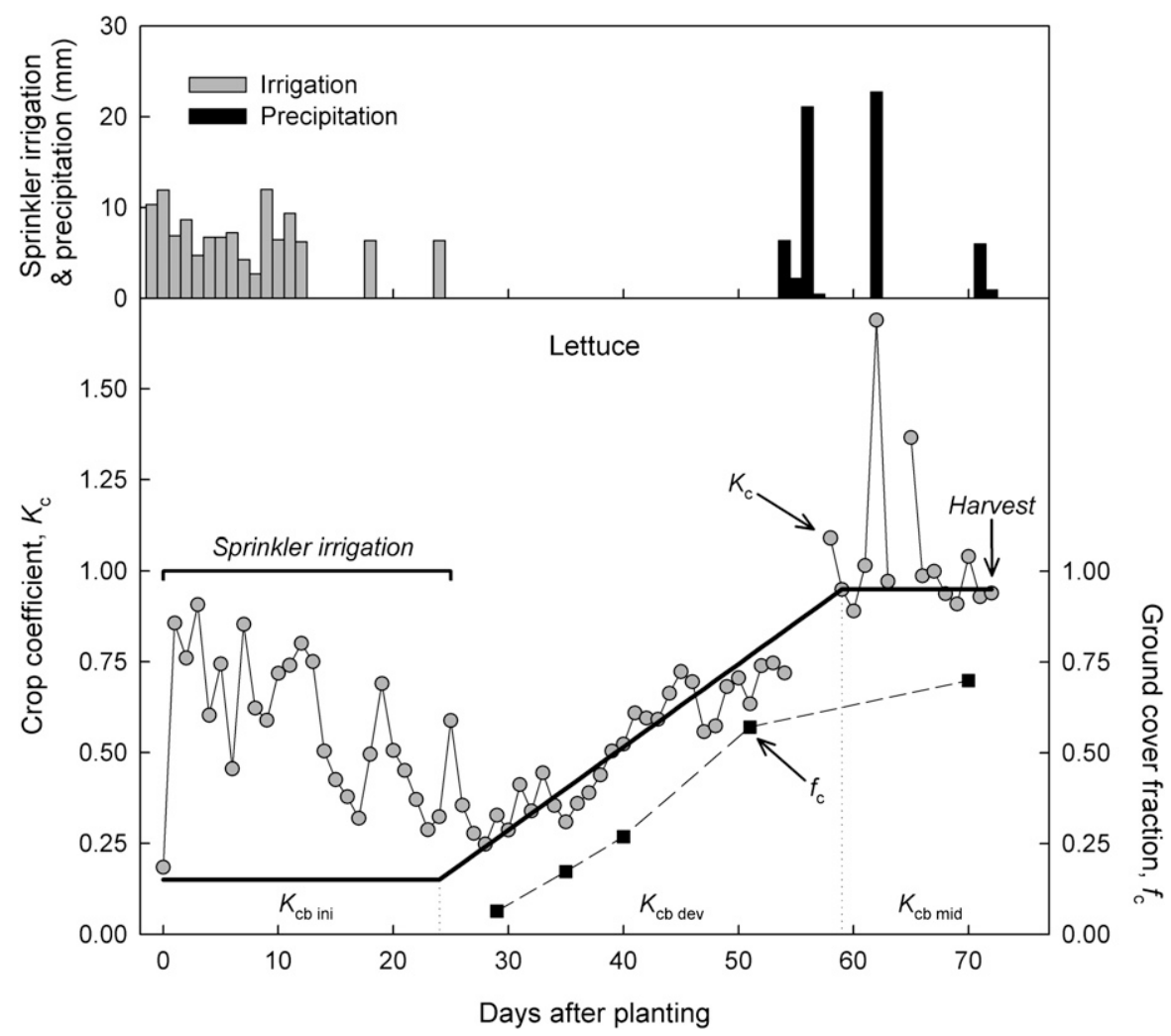

Fig. 5. Daily crop coefficients $\left(K_{\mathrm{c}}\right)$ and vegetative groundcover fraction $\left(f_{\mathrm{c}}\right)$ for iceberg lettuce from planting (24 Aug. 2004) to harvest (4 Nov. 2004). The heavy line represents the FAO segmented basal crop coefficient $\left(\mathrm{K}_{\mathrm{cb}}\right)$ curve at three stages of crop growth (initial period, $K_{\mathrm{cb}}$ ini; crop development period, $K_{\mathrm{cb} \text { dev }}$; and midseason period, $K_{\mathrm{cb} \text { mid }}$ ). Data are from Trout and Gartung (2006). between full effective cover to full maturity (initiation of flowering in many crops), and the late-season stage $\left(K_{\mathrm{cb}}\right.$ late $)$ that runs from full maturity to leaf senescence or harvest. The $K_{\mathrm{cb}}$ ini of each curve was set at 0.15 as recommended for vegetables in the FAO-56 publication (Allen et al., 1998). The midseason stage is often short in vegetable crops and in some cases may be the final stage if crops are harvested fresh for green vegetation (e.g., lettuce). The $K_{\mathrm{cb}}$ reaches its maximum value at midseason.

Broccoli. Broccoli (Brassica oleracea L. 'Captain') was transplanted in the crop lysimeter and field on 19 Aug. and harvested 2 Dec. 2002. Broccoli is produced primarily in fall and winter months in central California. Plants were grown in double rows on $1.0-\mathrm{m}$ wide raised beds with seedlings spaced $\approx 0.30$ to $0.35 \mathrm{~m}$ apart. The transplants were established to stand with sprinklers. Plants received a total of $198 \mathrm{~mm}$ of water over the season by subsurface drip irrigation plus an additional 22 $\mathrm{mm}$ of rain. In comparison, López-Urrea et al. (2009b) determined that the total consumptive water use for fall-planted, sprinkler-irrigated broccoli was $359 \mathrm{~mm}$, or $249 \mathrm{~mm}$ without soil evaporation, for a period of $109 \mathrm{~d}$ after transplanting in central Spain.

No lysimeter data were available in our study during the first $22 \mathrm{~d}$ after planting. However, assuming $K_{\mathrm{cb} \text { ini }}$ was equal to 0.15 , $K_{\mathrm{cb}}$ appeared to increase from $\approx 15$ to 57 $\mathrm{d}$ after planting and reached 1.0 at midseason (Fig. 4), which is 0.06 higher than the climateadjusted $K_{\mathrm{cb}}$ mid value listed for broccoli in

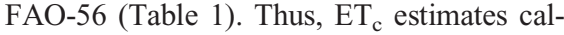
culated using FAO-56 differed from actual lysimeter $\mathrm{ET}_{\mathrm{c}}$ by a season total of only $13 \mathrm{~mm}$. There was little evidence of a late-season stage for $K_{\mathrm{cb}}$, not surprising because leaves on the plants were still green and succulent when the broccoli florets were harvested.

Broccoli harvested from the lysimeter averaged $0.32 \mathrm{~kg}$ (fresh weight) of marketable field-cut florets per plant, which is equivalent to $19.2 \mathrm{t} \cdot \mathrm{ha}^{-1}$ and higher than the $15 \mathrm{t} \cdot \mathrm{ha}^{-1}$ average for California (LeStrange et al., 1996). The crop also required considerably less irrigation than the 550 to $600 \mathrm{~mm}$ typically applied to the crop according to a local grower advisory group.

Lettuce. Iceberg lettuce (Lactuca sativa L.) was planted on 24 Aug. using pelleted seed and harvested on 4 Nov. 2004. Lettuce is produced primarily in fall and winter months in central California. Plants were grown in double rows on $1-\mathrm{m}$ wide raised beds and spaced $\approx 0.2 \mathrm{~m}$ apart after thinning. The field was sprinkler-irrigated daily beginning 2 $\mathrm{d}$ before and $12 \mathrm{~d}$ after planting until the seedlings emerged and at 18 and $24 \mathrm{~d}$ after planting to prepare the field for thinning and weeding. As a result, $K_{\mathrm{c}}$ values were high, in the range of 0.29 to 0.91 , during the initial stage of plant development as a result of soil evaporation from frequent soil surface wetting (Fig. 5).

The soil surface was dry during most of the crop development stage where $K_{\mathrm{cb}}$ increased between 24 and $59 \mathrm{~d}$ after planting as 


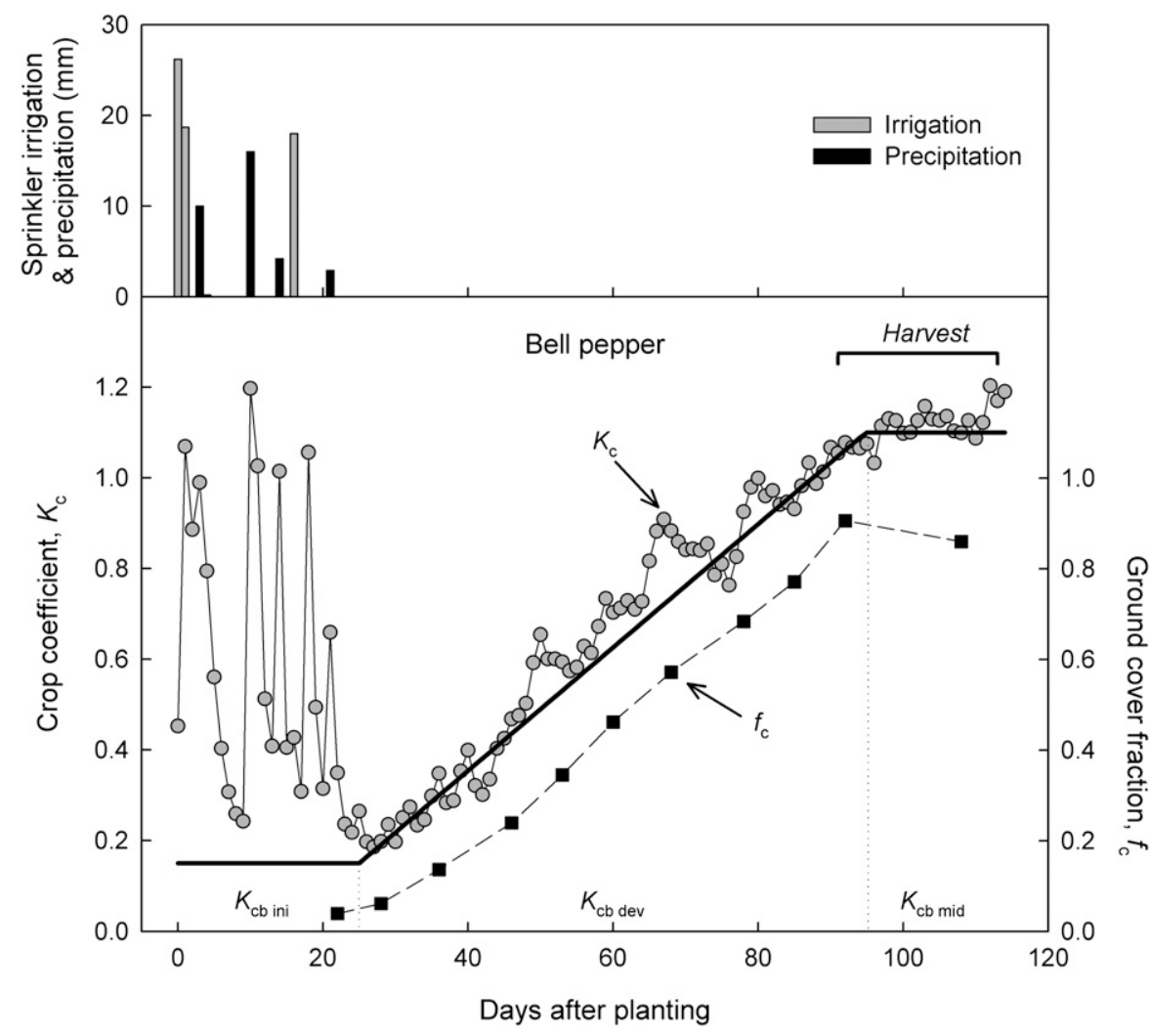

Fig. 6. Daily crop coefficients $\left(K_{\mathrm{c}}\right)$ and vegetative groundcover fraction $\left(f_{\mathrm{c}}\right)$ for bell pepper from planting (25 Apr. 2005) to harvest (25 July to 16 Aug. 2005). The heavy line represents the FAO segmented basal crop coefficient $\left(\mathrm{K}_{\mathrm{cb}}\right)$ curve at three stages of crop growth (initial period, $K_{\mathrm{cb}}$ ini; crop development period, $K_{\mathrm{cb} \text { dev }}$; and midseason period, $K_{\mathrm{cb} \text { mid }}$ ). Data are from Trout and Gartung (2006).

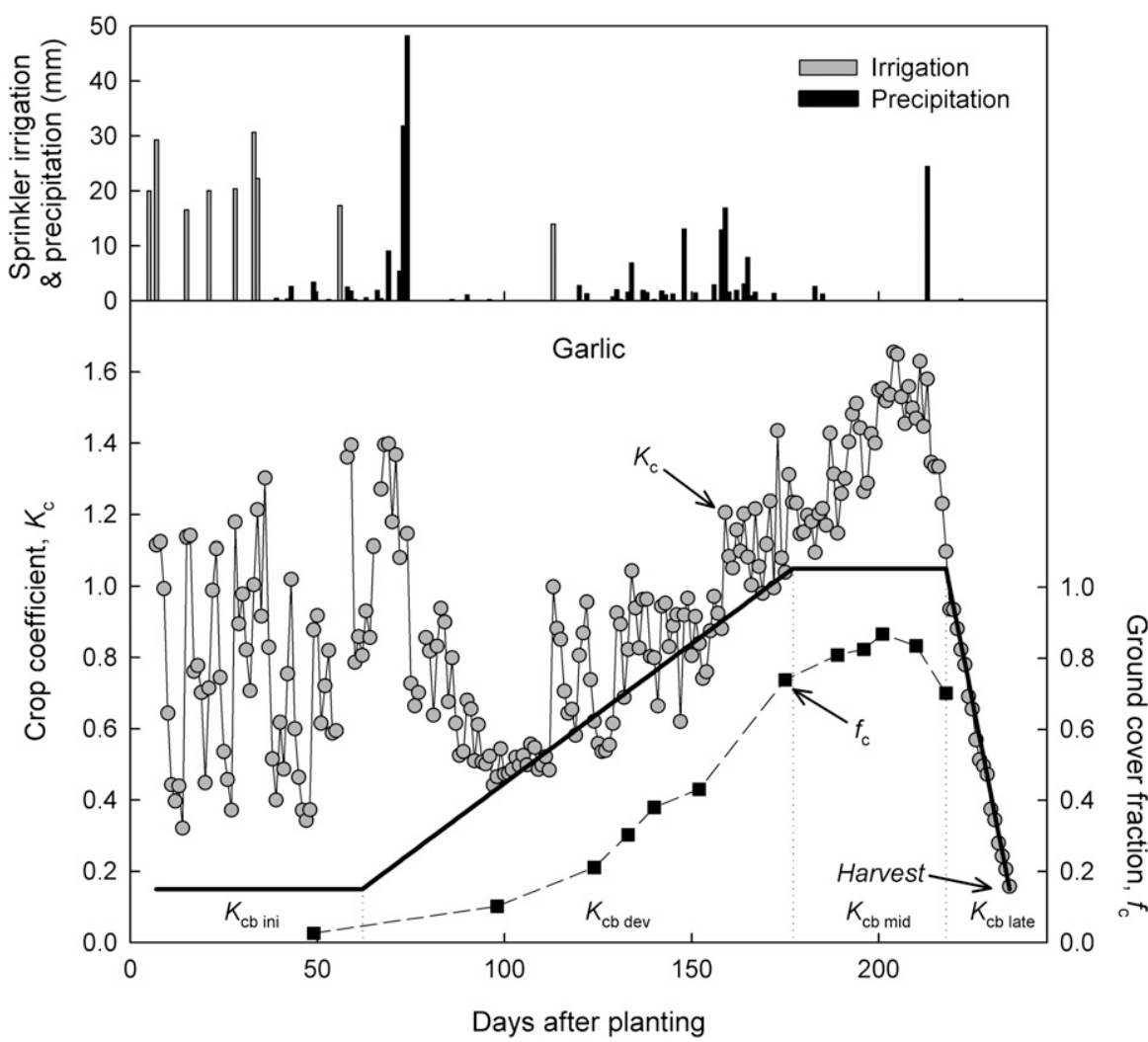

Fig. 7. Daily crop coefficients $\left(K_{\mathrm{c}}\right)$ and vegetative groundcover fraction $\left(f_{\mathrm{c}}\right)$ for garlic from planting $(25$ Oct. 2005) to harvest (12 June 2006). The heavy line represents the FAO segmented basal crop coefficient $\left(\mathrm{K}_{\mathrm{cb}}\right)$ curve at four stages of crop growth (initial period, $K_{\mathrm{cb} \text { ini; }}$; crop development period, $K_{\mathrm{cb} \mathrm{dev}}$; midseason period, $K_{\mathrm{cb} \text { mid }}$; and late-season period, $K_{\mathrm{cb} \text { late }}$. Data are from Ayars (2007). a function of the soil surface covered by the crop canopy. Peak $K_{\mathrm{cb}}$ at midseason was 0.95 with a final ground cover fraction at harvest of only $70 \%$, which is 0.07 higher than the climate-adjusted $K_{\mathrm{cb}}$ mid value listed for lettuce in FAO-56 (Table 1). Two spikes in $K_{\mathrm{c}}$ during the relatively short $(14 \mathrm{~d}) \mathrm{mid}-$ season stage were notable and likely the result of heavy rain. When $K_{\mathrm{cb}}$ mid is less than 1.0 , frequent wetting by rain or irrigation often increases $K_{\mathrm{c}}$ at midseason as a result of combined effects of continuously wet soil, evaporation off the plants at interception, and less boundary layer resistance as a result of roughness of the vegetation (Allen et al., 1998).

Lettuce yield in the field was $54 \mathrm{t} \cdot \mathrm{ha}^{-1}$, which, like broccoli, was higher than the 40 $\mathrm{t} \cdot \mathrm{ha}^{-1}$ average for California (Jackson et al., 1996). Plants received a total of $117 \mathrm{~mm}$ of water by sprinklers, $98 \mathrm{~mm}$ of water by subsurface drip irrigation, and $60 \mathrm{~mm}$ of rain, again lower than the amount typically applied in the region but comparable to the amount applied to lettuce in the central coast of California (Jackson et al., 1996).

Peppers. Bell pepper (Capsicum annuum L. 'Baron') was transplanted on 25 Apr. and harvested between 25 July and 16 Aug. 2005. Peppers are planted in spring and harvested as a summer crop in California's San Joaquin Valley. Plants were grown in a single row on $1-\mathrm{m}$ wide raised beds and spaced $0.25 \mathrm{~m}$ apart. The field was irrigated by sprinklers twice the first $2 \mathrm{~d}$ after planting and once at $16 \mathrm{~d}$ after planting; it also rained $4 \mathrm{~d}$ during the first 3 weeks after planting. The effects of the wetting events are evident as $K_{\mathrm{c}}$ increased sharply after each event, as high as 1.20 (Fig. 6).

The soil surface was dry during the crop development stage, a period that lasted $\approx 70$ $\mathrm{d}$, as ground cover increased from $\approx 5 \%$ to $90 \%$. Maximum $K_{\mathrm{cb}}$ at midseason was 1.10 , reached shortly after the first pepper harvest at $95 \mathrm{~d}$ after planting, and was similar to the adjusted value of 1.06 listed for bell pepper in FAO-56 (Table 1). The midseason stage was short and lasted only $18 \mathrm{~d}$ until harvest was done.

With no rain or sprinkler irrigation after the initial period, the soil surface was dry and therefore $K_{\mathrm{c} \mathrm{dev}} /$ mid was more or less equal to $K_{\mathrm{cb} \text { dev/mid. }}$ Allen et al. (1998) defined $K_{\mathrm{cb}}$ as the ratio of $\mathrm{ET}_{\mathrm{c}}$ over $\mathrm{ET}_{\mathrm{o}}$ when the soil surface is dry but transpiration is unlimited by soil water availability. Under limited soil water conditions, e.g., as a result of drought or high soil salinity, $K_{\mathrm{c}}$ declines and $K_{\mathrm{cb}}$ must be adjusted using a dimensionless stress coefficient, $K_{\mathrm{s}}$, dependent on available soil water [see Allen et al. (1998) and Doorenbos and Kassam (1979) for details]. Once pepper irrigation was ended after harvest, $K_{\mathrm{c}}$ declined within $25 \mathrm{~d}$ to 0.76 before any signs of leaf wilt (data not shown).

Marketable pepper yield in the field totaled $38 \mathrm{t} \cdot \mathrm{ha}^{-1}$, close to the $41 \mathrm{t} \cdot \mathrm{ha}^{-1}$ average for California (Hartz et al., 2007). Plants received a total of $63 \mathrm{~mm}$ of water by sprinklers, $561 \mathrm{~mm}$ of water by subsurface drip irrigation, and $33 \mathrm{~mm}$ of rain. 
Garlic. Garlic (Allium sativum spp. sativum L.) cloves were planted on 25 Oct. 2005 and harvested 12 June 2006. Garlic is mostly planted in early winter in California and harvested in summer. Plants were grown in double rows on $1-\mathrm{m}$ wide raised beds at a density of $\approx 60$ plants per meter. The field was sprinkler-irrigated until stand and later irrigated by subsurface drip. Irrigation was cutoff at 3 weeks before harvest (22 May) to dry the beds.

The garlic crop developed considerably slower than the other vegetables and required $\approx 170$ to $190 \mathrm{~d}$ of growth to reach $70 \%$ to $80 \%$ ground cover (Fig. 7). By this point, plants were irrigated only another $20 \mathrm{~d}$ before irrigation was ended to begin drying the soil and garlic bulbs for harvest. Unlike the other vegetable crops, garlic $K_{\mathrm{c}}$ never leveled off, even when ground cover exceeded $80 \%$. The $K_{\mathrm{cb} \text { mid }}$ value (1.0) illustrated in Figure 7 was chosen as the point at which $80 \%$ cover was reached; however, maximum $K_{\mathrm{cb}}$ was actually $\approx 1.3$. When the lysimeter was grown with garlic, daily minimum relative humidity at $K_{\mathrm{c} \text { mid }}$ averaged $25 \%$ and mean daily wind speed was $3.6 \mathrm{~m} \cdot \mathrm{s}^{-1}$, which partly accounts for the high $K_{\mathrm{c}}$ values observed at effective full cover (Table 1). Garlic $K_{\mathrm{c}}$, determined by an eddy covariance method, reached a maximum value of 1.2 to 1.3 under semiarid condition in Spain and declined to $\approx 0.6$ at harvest (Villalobos et al., 2004). In our study, garlic $K_{\mathrm{c}}$ at harvest ( $K_{\mathrm{c} \text { end }}$ ) was 0.16 and similar to $K_{\mathrm{cb} \text { ini, }}$, indicating the surface soil was very dry and the plant leaves were completely desiccated. The $K_{\mathrm{cb} \text { end }}$ listed for garlic in FAO-56 is 0.60 , and 0.68 after adjusting for climate, a value reached $\approx 10 \mathrm{~d}$ before harvest in the lysimeter.

Marketable yield of the garlic was 20 $\mathrm{t} \cdot \mathrm{ha}^{-1}$, slightly higher than the $18 \mathrm{t} \cdot \mathrm{ha}^{-1}$ average for California (California Agricultural Statistical Service, 2006). Crop water

Table 1. Midseason basal crop coefficients ( $\left.K_{\mathrm{cb} \text { mid }}\right)$ for vegetable crops in the San Joaquin Valley of California.

\begin{tabular}{lcccc}
\hline Parameter & Broccoli & Lettuce & Bell pepper & Garlic \\
\hline Lysimeter $K_{\mathrm{cb} \text { mid }}$ & 1.00 & 0.95 & 1.10 & 1.00 \\
FAO $K_{\mathrm{cb} \text { mid }}$ & 0.95 & 0.90 & 1.00 & 0.90 \\
Midseason conditions & & & & 3.0 \\
$\quad$ Wind speed, $u_{2}\left(\mathrm{~m} \cdot \mathrm{s}^{-1}\right)$ & 1.9 & 1.5 & 2.7 & 35 \\
$\quad \mathrm{RH}_{\text {min }}(\%)$ & 47 & 52 & 0.6 & 0.6 \\
$\quad$ Plant height, $h$ & 0.6 & 0.3 & 1.06 & 0.95 \\
Adjusted $K_{\mathrm{cb} \text { mid }}$ & 0.94 & 0.88 & 95-114 & $177-218$ \\
Midseason stage & $57-105$ & $59-72$ & 29 July to & 15 Apr. to \\
$\quad$ Days after planting & 15 Oct. to & 22 Oct. to & 16 Aug. 2005 & 26 May 2006 \\
$\quad$ Dates & 2 Dec. 2002 & 4 Nov. 2004 & & \\
\end{tabular}

${ }^{\mathrm{z}}$ Values from FAO Irrigation and Drainage Paper 56 (Allen et al., 1998).

${ }^{\mathrm{y}} \mathrm{FAO} K_{\mathrm{cb}}$ mid values $\left[K_{\mathrm{cb}}\right.$ mid (Tab) $]$ are adjusted for climate when minimum relativity humidity $\left(\mathrm{RH}_{\mathrm{min}}\right)$ at the midseason growth stage differs from $45 \%$ and wind speed $\left(u_{2}\right)$ at $2 \mathrm{~m}$ height over grass is larger or smaller than $2 \mathrm{~m} \cdot \mathrm{s}^{-1}$, as follows: $K_{c b \text { mid }}=K_{c b \text { mid }(T a b)}+\left[0.04\left(u_{2}-2\right)-0.004\left(R H_{\min }-45\right)\right]\left(\frac{h}{3}\right)^{0.3}($ Allen et al., 1998).
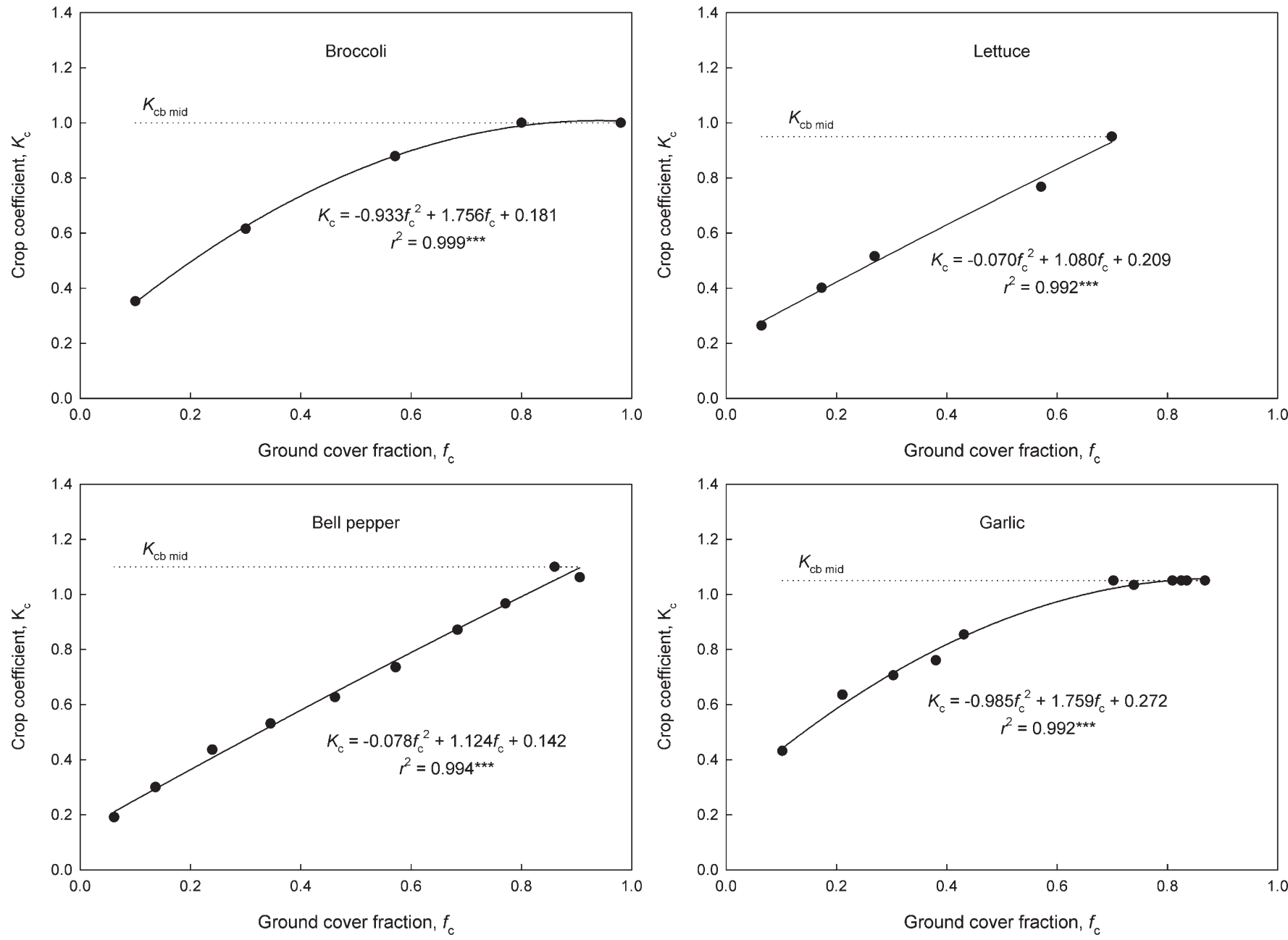

Fig. 8. Relationship between the basal crop coefficient, $K_{\mathrm{cb}}$, and ground cover fraction, $f_{\mathrm{c}}$, in broccoli, iceberg lettuce, bell pepper, and garlic. Data are from Figures 4 through 7 . $* * * P<0.001$. 
use measured by the lysimeter between 1 Mar. (142 d after planting) and irrigation cutoff on 22 May totaled $425 \mathrm{~mm}$ with 108 $\mathrm{mm}$ of rain during this period.

\section{RELATIONSHIP BETWEEN BASAL CROP COFFICIENTS AND GROUND COVER}

Recent lysimeter studies have explored the relationship between crop coefficients and ground cover in various horticultural crops, including vegetables, fruit trees, and grapevines, and have found that $K_{\mathrm{cb}}$ is often linearly correlated to canopy light interception or shaded area (Johnson et al., 2000, 2002; Trout et al., 2008; Williams and Ayars, 2005). Generalized relationships of this sort would allow weather-based irrigation scheduling for a wide range of horticultural crops based on simple canopy measurements or possibly based on remotely sensed vegetation indices (Trout and Johnson, 2007; Trout et al., 2008). Because light interception other than at midday and aerodynamic roughness of the plant surface will depend on the canopy structure, adjustments to these simple linear models may be needed for taller crops (Allen and Pereira, 2009).

Gratten et al. (1998) developed non-linear relationships between ground cover and crop coefficients for vegetable and row crops in California using the Bowen ratio method to determine crop ET. They concluded that $K_{\mathrm{c}}$ changed as a quadratic function of percentage ground cover. Quadratic relationships between $K_{\mathrm{cb}}$ and ground cover fraction, $f_{\mathrm{c}}$, were also evident when plotted using the lysimeter data, although linear fits were good before midseason, especially when the crop's midseason was short, e.g., in lettuce and bell pepper (Fig. 8).

Allen and Pereira (2009) recently formalized the FAO-56 procedure for estimating $K_{\mathrm{c}}$ as a function of fraction of ground cover and crop height using a density coefficient, $K_{\mathrm{d}}$, whereby $K_{\mathrm{d}}$ is multiplied by $K_{\mathrm{c}}$ representing full cover conditions, $K_{\mathrm{cb} \text { full }}$, to produce a $K_{\mathrm{cb}}$ representing the actual condition of ground cover. The authors note that the method does not replace ET measurement for developing crop coefficient curves, but it does provide a means to estimate change in $K_{\mathrm{c}}$ values with increases (or decreases, e.g., as a result of insect herbivory) of ground cover.

\section{COMPARISON OF LYSIMETER AND CIMIS EVAPOTRANSPIRATION}

CIMIS $\mathrm{ET}_{\mathrm{o}}$ was evaluated in 2004 and 2005 using data collected from the grass lysimeter and the CIMIS weather station (Vaughn et al., 2007). When daily $\mathrm{ET}_{\mathrm{o}}$ was less than $6 \mathrm{~mm} \cdot \mathrm{d}^{-1}, \mathrm{ET}_{\mathrm{o}}$ values calculated using either the Pruitt-Doorenbos (Pruitt and Doorenbos, 1977) or the Penman-Monteith (Allen et al., 1989) models were in good agreement with daily $\mathrm{ET}_{\mathrm{o}}$ measured by the lysimeter. However, when $\mathrm{ET}_{\mathrm{o}}$ was greater than $6 \mathrm{~mm} \cdot \mathrm{d}^{-1}$, CIMIS predictions of $\mathrm{ET}_{\mathrm{o}}$ were less than lysimeter $\mathrm{ET}_{\mathrm{o}}$ and the relation- ship between the two was slightly non-linear. The importance of this difference is illustrated in measurement of $K_{\mathrm{c}}$ for garlic. In this case, ET demands were high as the crop approached midseason. Crop coefficients were 0.19 lower on average if lysimeter $\mathrm{ET}_{\mathrm{o}}$ was used to calculate garlic $K_{\mathrm{c}}$ whenever CIMIS $\mathrm{ET}_{\mathrm{o}}$ was higher than $6 \mathrm{~mm} \cdot \mathrm{d}^{-1}$ and the crop was irrigated.

Vaughn et al. (2007) also found that the correlation between CIMIS and lysimeter $\mathrm{ET}_{\mathrm{o}}$ was poor at night. Because $\mathrm{ET}_{\mathrm{o}}$ is sometimes substantial at night, identification of specific atmospheric conditions on such nights may lead to better weather-based predictions.

\section{SUMMARY AND CONCLUSIONS}

Weighing lysimeters are useful tools for measuring crop water requirements and developing $K_{\mathrm{c}}$ curves in horticultural crops. Crop coefficient curves were developed using the WSREC lysimeters in broccoli, lettuce, bell pepper, and garlic in central California. Basal crop coefficients, $K_{\mathrm{cb}}$, which represent primarily the transpiration component of crop ET, increased linearly or curve linearly with crop development and, with the exception of garlic, reached maximum $K_{\mathrm{cb}}$ once ground cover was greater than $70 \%$ to $90 \%$. When the data were fit using the FAO segmented approach, basal crop coefficients at midseason or $K_{\mathrm{cb} \text { mid }}$ were within 0.04 to 0.07 of those listed for each crop in FAO-56; however, the $K_{\mathrm{cb}}$ end value listed for garlic differed considerably and was 0.5 lower in the lysimeter. This latter difference may reflect the level in which the crop is dried before harvest. It was not possible to determine basal crop coefficients during initial stages of crop growth, $K_{\mathrm{cb}}$ ini, because frequent sprinkler irrigation or rain was needed at this stage to establish the crops. A possible method to determine $K_{\mathrm{cb}}$ ini might be to measure lysimeter ET before planting, before any rain or surface irrigation water is applied.

Results of this work are helping California's farmers select irrigation systems and management strategies that can increase profitability for growing crops in the San Joaquin Valley and increase economic value per unit of water used. It also helps irrigation managers and consultants make better recommendations regarding irrigation in the region. Improving irrigation management reduces seasonal water requirements, allowing farmers to maintain yields with less water, even in the event of reduced water allocations, and perhaps use the saved water for production of other crops. Many benefits result from application of improved $K_{\mathrm{c}}$ values, in particular higher irrigation water use efficiency, especially when used in conjunction with proper irrigation system maintenance. Using 369,000 ha of irrigated vegetables harvested in California in 2008 as a basis, and assuming that an average of 600 $\mathrm{mm}$ of water is typically applied per crop, a $10 \%$ water savings from the use of crop coefficients and more accurate irrigation scheduling practices could result in 221,000,000 $\mathrm{m}^{3}$ of water saved per year.

\section{Literature Cited}

Allen, R.G., M.E. Jensen, J.L. Wright, and R.D. Burman. 1989. Operational estimates of reference evapotranspiration. Agron. J. 81:650-662.

Allen, R.G. and L.S. Pereira. 2009. Estimating crop coefficients from fraction of ground cover and height. Irrig. Sci. 28:17-24.

Allen, R.G., L.S. Pereira, D. Raes, and M. Smith. 1998. Crop evapotranspiration. Guidelines for computing crop water requirements. FAO Irrigation and Drainage Paper 56. Food and Agriculture Organization of the United Nations, Rome, Italy.

Allen, R.G., W.O. Pruitt, and M.E. Jensen. 1991. Environmental requirements of lysimeters, $\mathrm{p}$. 170-181. In: Allen, E.G., T.A. Howell, W.O. Pruitt, I.A. Walter, and M.E. Jensen (eds.). Lysimeters for evapotranspiration and environmental measurements. ASCE Publications, New York, NY.

ASCE-EWRI. 2005. The ASCE standardized reference evapotranspiration equation. Allen, R.G., I.A. Walter, R.L. Elliott, T.A. Howell, D. Itenfisu, M.E. Jensen, and R.L. Snyder (eds.). Amer Soc. Civil Eng., App. A-F and Index, 69 p. Reston, VA

Ayars, J.E. 2007. Water requirement of irrigated garlic. Proc. ASABE 51:1683-1688.

Ayars, J.E., C.J. Phene, R.B. Hutmacher, K.R. Davis, R.A. Schoneman, S.S. Vail, and R.M. Mead. 1999. Subsurface drip irrigation of row crops: A review of 15 years of research at the Water Management Research Laboratory. Agr. Water Mgt. 42:1-27.

California Agricultural Statistical Service. 2006. Agricultural commissioners' data, 2005. Calif. Dept. Food Agr.

Doorenbos, J. and A.H. Kassam. 1979. Yield response to water. FAO Irrigation and Drainage Paper 33. Food and Agriculture Organization of the United Nations, Rome, Italy.

Evett, S.R., T.A. Howell, A.D. Schneider, D.R. Upchurch, and D.F. Wanjura. 2000. Automatic drip irrigation of corn and soybean, p. 401-408. National Irrigation Symposium. Proc. 4th Decennial Symposium, Amer. Soc. Agr. Eng., St. Joseph, MI.

Gratten, S.R., W. Bowers, A. Dong, R.L. Snyder, J.J. Carroll, and W. George. 1998. New crop coefficients estimate water use of vegetables, row crops. Calif. Agr. 52:16-21.

Harold, L.L. and F.R. Dreibelbis. 1951. Agricultural hydrology as evaluated by monolith lysimeters. U.S. Dept. Agric. Tech. Bull. No. 1050.

Hartz, T., M. Cantwell, M. LeStrange, R. Smith, J. Aguiar, and O. Daugovish. 2007. Bell pepper production in California. Univ. Calif. Div. Agric. Natural Resources Publication 7217.

Howell, T.A., R.L. McCormick, and C.J. Phene 1985. Design and installation of large weighing lysimeters. Trans. ASAE 28:106-112.

Howell, T.A., A.D. Schneider, and M.E. Jensen. 1991. History of lysimeter design and use for evapotranspiration measurements, p. 1-9. In: Allen, R.G., T.A. Howell, W.O. Pruitt, I.A. Walter, and M.E. Jensen (eds.). Lysimeters for evapotranspiration and environmental measurements. ASCE Publications, New York, NY.

Jackson, L., K. Mayberry, F. Laemmlen, S. Koike, K. Schulbach, and W. Chaney. 1996. Iceberg lettuce production in California. Univ. Calif. Div. Agric. Natural Resources Publication 7215.

Johnson, R.S., J. Ayars, and T. Hsaio. 2002. Modelling young peach tree evapotranspiration. Acta Hort. 584:107-113.

Johnson, R.S., J. Ayars, and T. Trout. 2000. Crop coefficients for mature peach trees are well correlated with mid-day canopy light interception. Acta Hort. 537:455-460. 
LeStrange, M., K.S. Mayberry, S.T. Koike, and J. Valencia. 1996. Broccoli production in California. Univ. Calif. Div. Agric. Natural Resources Publication 7211.

López-Urrea, R., A. Montoro, J. Gonzalez-Piqueras, P. López-Fuster, and E. Fereres. 2009a. Water use of spring wheat to raise productivity. Agr. Water Mgt. 96:1305-1310.

López-Urrea, R., A. Montoro, P. López-Fuster, and E. Fereres. 2009b. Evapotranspiration and responses to irrigation of broccoli. Agr. Water Mgt. 96:1155-1161.

López-Urrea, R., F. Martín de Santa Olalla, A. Montoro, and P. López-Fuster. 2009c. Single and dual crop coefficients and water requirements for onion (Allium cepa L.) under semiarid conditions. Agr. Water Mgt. 96:1031-1036.

Lourence, F. and R. Moore. 1991. Prefabricated weighing lysimeter for remote research stations, p. 432-439. In: Allen, R.G., T.A. Howell, W.O. Pruitt, I.A. Walter, and M.E. Jensen (eds.). Lysimeters for evapotranspiration and environmental measurements. ASCE Publications, New York, NY.

Lovelli, S., S. Pizza, T. Caponio, A.R. Rivelli, and M. Perniola. 2005. Lysimetric determination of muskmelon crop coefficients cultivated under plastic mulches. Agr. Water Mgt. 72:147-159.

Malone, R.W., J.V. Bonta, D.J. Stewardson, and T. Nelson. 2000. Error analysis and quality improvement of the Coshocton weighing lysimeter. Trans. ASAE 43:271-280.

Nielsen, D.R., J.W. Biggar, and K.T. Her. 1973. Spatial variability of field-measured soil water properties. Hilgardia 42:215-260.

Phene, C.J., R.L. McCormick, K.R. Davis, J.D. Pierro, and D.W. Meek. 1989. A lysimeter feedback irrigation controller system for evapotranspiration measurements and real time irrigation scheduling. Trans. ASAE 32:477-484.
Phene, C.J., R.L. McCormick, J.M. Miyamoto, D.W. Meek, and K.R. Davis. 1985. Evapotranspiration and crop coefficients of trickle irrigated tomatoes. Proc. 3rd Intl. Drip/Trickle Irrigation Congress, Fresno, CAASAE Publication No. 10-85823-831.

Piccinni, G., J. Ko, T. Marek, and D.I. Leskovar. 2009. Crop coefficients specific to multiple phenological stages for evapotranspirationbased irrigation management of onion and spinach. HortScience 44:421-425.

Pruitt, W.O. and J. Doorenbos. 1977. Empirical calibration a requisite for evaporation formulae based on daily or longer mean climatic data? International Commission on Irrigation and Drainage Conference on Evapotranspiration, Budapest, Hungary, 26-28 May.

Pruitt, W.O. and F.J. Lourence. 1985. Experiences in lysimetry for ET and surface drag measurements, p. 51-69. In: Advances in evapotranspiration: Proc. National Conf. on Advances in Evapotranspiration. ASCE Publ. No. 14-85. St. Joseph, MI.

Schneider, A.D., T.A. Howell, and A.T.A. Moustafa. 1998. A simplified weighing lysimeter for monolithic or reconstructured soils. Trans. Appl. Eng. Agr. 14:267-273.

Snyder, R.L., B.J. Lanini, D.A. Shaw, and W.O Pruitt. 1987a. Using reference evapotranspiration (ETo) and crop coefficients to estimate crop evapotranspiration (ETc) for agronomic crops, grasses, and vegetable crops. Univ. Calif. Div. Agric. Natural Resources, Leaflet 21427.

Snyder, R.L., B.J. Lanini, D.A. Shaw, and W.O. Pruitt. 1987b. Using reference evapotranspiration (ETo) and crop coefficients to estimate crop evapotranspiration (ETc) for trees and vines. Univ. Calif. Div. Agric. Natural Resources, Leaflet No. 21428.
Trout, T. and G. Gartung. 2006. Use of crop canopy size to estimate crop coefficients for vegetable crops. ASCE Conf. Proc. 200:297-303.

Trout, T.J. and L.F. Johnson. 2007. Estimating crop water use from remote sensed NDVI, crop models, and reference ET, p. 275-285. In: The role of irrigation and drainage in a sustainable future. Proc. USCID Fourth International Conference on Irrigation and Drainage, Sacramento, CA.

Trout, T.J., L.F. Johnson, and J. Gartung. 2008. Remote sensing of canopy cover in horticulture crops. HortScience 43:333-337.

USDA NASS. 2009. 2008 Farm and ranch irrigation survey. U.S. Department of Agriculture, National Agricultural Statistics Service.

Vaughn, P.J. and J.E. Ayars. 2009. Noise reduction methods for weighing lysimeters. J. Irrig. Drain. Eng. 135:235-240.

Vaughn, P.J., T.J. Trout, and J.E. Ayars. 2007. A processing method for weighing lysimeter data and comparison to micrometeorological ETo predictions. Agr. Water Mgt. 88:141-146.

Villalobos, F.J., L. Testi, R. Rizzalli, and F. Orgaz. 2004. Evapotranspiration and crop coefficients of irrigated garlic (Allium sativum L.) in a semi-arid climate. Agr. Water Mgt. 64:233-249.

Williams, L.E. and J.E. Ayars. 2005. Grapevine water use and crop coefficient are linear functions of the shaded area measured beneath the canopy. Agr. For. Meteorol. 132:201-211.

Williams, L.E., C.J. Phene, D.W. Grimes, and T.J. Trout. 2003a. Water use of young Thompson Seedless grapevines in California. Irrig. Sci. 22:1-9.

Williams, L.E., C.J. Phene, D.W. Grimes, and T.J. Trout. 2003b. Water use of mature Thompson Seedless grapevines in California. Irrig. Sci. 22:11-18.

Wright, J.L. 1982. New evapotranspiration crop coefficients. J. Irrig. Drain. Div. 108:57-74. 